\title{
Evaluation of Online Hotel Booking Services in Uzbekistan
}

\author{
Ph.D. Candidate Sitora Inoyatova (Tashkent State University of Economics, Uzbekistan) \\ Prof. Dr. Obidjon Khamidov (Tashkent State University of Economics, Uzbekistan) \\ Ph.D. Candidate Asror Nigmonov (University of Southern Queensland, Uzbekistan)
}

\begin{abstract}
Nowadays, trend towards the online hotel booking has been increased throughout the world. Hotels can directly offer online room booking service to prospective customers through their website, which reduces the need of booking through giant commercial online hotel booking services. Main objective of this article is to analyze and have an actual picture of the online booking systems in the hotels of Uzbekistan.

With the aim of meeting the objective of the article the qualitative method shall be used by conducting the website analysis, personal evaluation, and open to public statistics resources. The paper will be based on the literature review of similar research conducted by other authors within the area of online hotel booking, which brings great interest to the researchers, since there is very little research has been conducted on same area in Uzbekistan, which makes it very difficult to obtain valid resource which would demonstrate the current online hotel booking service level integration in the country.

In conclusion, the results of the research shall be presented, where the current situation of online booking services by hotels' website would be represented with the present features used by the local hotels, along with the areas for further development and recommendations will be made in order to boost the development of the country hotels' online booking systems.
\end{abstract}

\section{Introduction}

We live the era of XXI century, and with the invention of the Internet most of things that people are doing and working on is done through Internet. Number of internet users all over the world as of 31 December 2017 is estimated to 4,156,932,140 users which represents 54.4\% penetration rate (Internet World Stats, 2017).

There is a huge access to the information nowadays, which resulted in growth of new industries such as social media, social marketing, e-commerce, electronic businesses and so on. The way that businesses used to do business before has completely altered; today most of the businesses need to have a corporate website and need to be easily reached through Internet so that more consumers have access to. On the other hand, there are number of businesses that do not maintain their corporate websites at all, and instead, they create pages on Facebook and Instagram to reach more customers. This article is going to look at the current state of the hotel online booking systems through the corporate websites in Uzbekistan. There is a limited research within this area in Uzbekistan, that is why it is personal interest to the researchers to analyze the current level of website presence by hotels of Uzbekistan, and the level of openness to the global potential consumers.

\section{Online Hotel Booking}

According to Marcussen (2008), the number of tourists using online booking tools is increasing with rapid speed. The top list of online tourist sales is comprised of $54 \%$ by air travel, $19.5 \%$ by hotels, $15 \%$ by package tours, $7 \%$ by rail, and $4 \%$ by car rentals.

To date, there are several methods through which a hotel can be booked by travelers. Tourists book a hotel directly (through email, phone, reservation offices or website), or through third party channel such as travel agencies and Online Travel Agencies (OTA). There are four systems aimed at processing booking requests such as (1) Global Distribution Systems (GDS) such as Amadeus, Sabre, Galileo, Worldspan through which allocation of hotel rooms takes place electronically; (2) Central Reservation System (CSR); (3) switch system (e.g. Thisco, Wizcom), through which CRS is connected to GDS, and (4) Property Management System (PMS) to which CRS is connected in order to show booking data on the hotels' reservation front desk (Choi and Kimes, 2002).

According to Statista (2014), in 2014, 29\% of Britons used general holiday booking website, $25 \%$ used travel agent online, $21 \%$ directly with a tour operator, and $20 \%$ high street travel agent. As for the interesting statistics, $83 \%$ of Britons have booked their holiday using online methods in 2017 (Holiday Habits Report, 2017). According to Failte Ireland 2012, 70\% of overseas tourists traveling to Ireland booked their accommodation through Internet (Failte Ireland National Tourism Development Authority, 2013). 62\% of online hotel booking in Dubrovnik, Croatia has been made by individual tourists who came with leisure purposes (Crnojevac et al., 2009).

It is interesting to understand how travelers who preferred online booking tools made the decision to select that particular hotel; in particular, whether it was because of the corporate hotel's website. There also has been a number of research studies conducted to evaluate the relationship between corporate website and its effectiveness on sales and promotion (Chan and Law, 2006, cited in Inversini and Masiero, 2014). It has been found that customers decision to book a hotel is dependent on the appearance of the website especially those which include the photos, 
and then theme, color scheme, ease of use (Phelan et al., 2011). In another study, it has been revealed that there is a positive correlation between the quality of economy hotel corporate websites in China and online booking intention by the consumers (Li et al., 2017). Which provides some arguments for the positive effects of maintaining the corporate website. It is interesting to note that in China economy hotel industry is thriving to boost online direct sales rather than through the third-party companies which are charging high commissions (Li et al., 2017).

Even though there are hotels which use the full potential of Internet and upgrade and improve their corporate websites for being more user-friendly, modern, contain more quality information, there are still hotels which neglect the importance of corporate websites as being main tool for communicating with customers; they have big gaps in handling online booking inquiries through their websites namely by email, online booking forms, etc (Gardini, 2015).

In a study of 111 hotels in Germany, Switzerland and Austria, it has been revealed that hotels are not fully using all tools to market themselves through corporate websites (e.g. lack of various contact information, poor quality responses, lack of virtual tours and 360' degrees view of rooms, non-availability of hotel information online, which is a demonstration of poor online inquiries handling (Gardini, 2015). Around 30\% of hotels and 20\% of tourism offices left emails from potential customers without a response (ServiceQualita $t$ Niedersachsen, 2006, cited in Gardini, 2015). It has also been found that difficult to use hotel websites negatively affect online booking and 'revisit intentions'(Essawy, 2006, cited in Dickinger and Mazanec, 2008). Another challenge for hoteliers, is that hotels' websites in Malaysia, for example, have a lot of online visitors, however could not provide an online booking service for its customers (Abdullaha et al., 2015).

Importantly to our research topic, it has been found out that it is very important that hotel website is easily located or 'found' through the internet, because OTA sites, are located without much effort compared to the hotels' websites (Miller, 2004 in N.K. Liu and E.Y. Zhang 2014). Thus, it is important for hotels to consider developing its search engine marketing strategy (Ho et al., 2011, in N.K. Liu and E.Y. Zhang 2014).

Hospitality industry is a highly competitive industry with a lot of opportunities which can be reached through internet, hotels are looking into ways of increasing their sales, cutting costs, improving brand image and reputation full use of handling inquires and converting them into sales i.e. consumers. With the increased competition from OTAs, hoteliers have to balance out their corporate websites and internet distribution channels by being present on social media and OTA sites, despite the commission rates, because this is the price for staying competitive nowadays (Inversini and Masiero, 2014).

To date, there are several OTAs among which researchers have identified the top three (3) such as Booking.com, TripAdvisor and Expedia. Through OTAs, as was discussed earlier travelers have access to wide range of online booking options starting from flight ending with car rentals (Alexa, 2018). The Table 1 below constructed by the researchers, summarizes the daily page reviews, daily time spent by users on site, monthly visitors and brief information about the unique function and option that each OTA offers to its customers.

\begin{tabular}{|c|c|c|c|c|c|c|}
\hline $\mathrm{s} / \mathrm{n}$ & Website & Information & $\begin{array}{l}\text { Daily } \\
\text { page } \\
\text { reviews } \\
\text { per } \\
\text { visitor }\end{array}$ & $\begin{array}{l}\text { Daily } \\
\text { time } \\
\text { on site }\end{array}$ & $\begin{array}{l}\text { Total } \\
\text { sites } \\
\text { linking } \\
\text { in }\end{array}$ & $\begin{array}{l}\text { Monthly } \\
\text { visitors } \\
\text { (est. 2018) }\end{array}$ \\
\hline 1 & Booking.com & $\begin{array}{l}\text { Online Travel Agent (OTA) - agency business } \\
\text { model (Innovation Tactics, 2017). } \\
\text { Hotel and similar accommodations' online } \\
\text { booking platform. }\end{array}$ & 4.67 & 09:08 & 74,671 & $40,000,000$ \\
\hline 2 & TripAdvisor & $\begin{array}{l}\text { Online Travel Agent (OTA) - advertising } \\
\text { business model (Innovation Tactics, 2017). } \\
\text { Travelers' reviews and service star ratings for } \\
\text { hotels and similar tourist attractions with price } \\
\text { comparison option. }\end{array}$ & 2.75 & 3.08 & 103,359 & $38,000,000$ \\
\hline 3 & Expedia & $\begin{array}{l}\text { Online Travel Agent (OTA) - merchant business } \\
\text { model (Innovation Tactics, 2017). } \\
\text { Aimed for tourist planning needs (e.g. vacation } \\
\text { plans, flights, hotels, car rentals, cruises, } \\
\text { attractions etc.) }\end{array}$ & 3.49 & 5.46 & 9,308 & $25,000,000$ \\
\hline
\end{tabular}

Table 1. Top Ranked Sites in Travel Category Source: eBizMBAGuide, 2018 and Alexa, 2018.

Booking.com founded in 1996 in Amsterdam operates in 70 countries all over the world, available in more than 40 languages including 28,475,497 reported listings and 131,438 destinations in 228 countries. Takes first place among top travel websites followed by TripAdvisor and Expedia by offering hotel and similar accommodations online booking services (Booking.com, 2018). 
TripAdvisor established in 2000 is in the top three list for travelers sites with 7.5 million accommodations, airlines and other travel destination reviews and ratings, providing its services in 48 markets across the world as of 2018 and most importantly displaying information on 600 million consumer reviews and recommendations, which enables its users to gain access to price comparison data from more than 200 booking sites (TripAdvisor, 2018).

Expedia founded in 1996 and operating in 33 countries is in the top 3 list for travelers' websites with 25 million monthly visitors, offering wide portfolio of services starting from booking of hotel, flight, cruises ending with car rental (Expedia, 2018). Expedia is part of Expedia Group which includes wide range of world known travel brands such as Hotels.com, Expedia Affiliate Network, Egencia, trivago, Homeaway, Orbitz, Travelocity, Expedia Local Expert and others (Expedia, 2018).

It is interesting to note, that $45 \%$ of individual travel plans and $54 \%$ of business travel plans are made by tourists in accordance with the customer ratings and comments (Google and OTX, 2011, cited in Cezar and Ogut, 2012). Liu and Zhang (2014), found out that consumers prefer to book a hotel through online travel agent website mainly because they are better at providing wider information with the only positive aspect (for hoteliers) that hotel corporate websites represent higher quality which acts as their competitive advantage such as latest photographs, updates, information etc., which means that hoteliers can use it as their competitive advantage. It has been found that online consumer rating of the hotel boosts the online sales and not the number of stars the hotel has (Ogut and Tas, 2011, cited in Cezar and Ogut, 2012). In a study analyzing the relationship between customer online ratings and the decision-making process, it has been found that both good and bad online customer reviews and ratings increase customer decision making process (Vermuelen and Seegers, 2009, cited in Cezar and Ogut, 2012).

It has been identified that online booking system has a significant impact on improvement of the sales, hence financial performance of the hotels (Sanchez and Satir, 2005, cited in Abdullah et al., 2015). Based on research findings of various authors, cannot neglect the importance of online customer reviews which both influences the image of the hotel as well as its financial performance i.e. sales.

\section{Method}

The qualitative method shall be used by conducting the website analysis, personal evaluation, and open to public statistics resources of hotels in Uzbekistan. We shall conduct a research evaluation of the hotels' corporate websites during January to March 2018 time period and collect data from the online websites of GoldenPages (2018), YellowPagesUzbekistan (2018), the State Committee of the Republic of Uzbekistan on Statistics (2018) as well as TripAdvisor, Booking.com, and Expedia. The main aim of the research is to evaluate the current situation of online booking services used by hotels' websites.

\section{Analysis and Findings}

According to the State Committee of the Republic of Uzbekistan on Statistics (2017), there are around 750 hotels and similar accommodations in Uzbekistan as of 2016, which indicates an increase by $44 \%$ (229 hotels more) compared to 2012 (521 hotels). Based on YellowPagesUzbekistan (2018), there are 271 hotels and similar accommodations and 276 based on GoldenPages (2018). Also, interesting to note that according to the Booking.com (2018), there are listed 204 hotels, and in total 322 hotels and similar accommodations in Uzbekistan, making a total of 322 facilities listed. Whereas, according to TripAdvisor (2018), there are 132 hotels listed, 241 B\&B accommodations and 123 specialty lodging, making a total of 496 facilities listed. According to Expedia (2018), there are 110 hotels and similar accommodations listed.

Based on the self-constructed by researchers Table 2, Out of 750 hotels and similar accommodations reported by the State Committee of the Republic of Uzbekistan on Statistics, 496 (66.1\%) are listed in the TripAdvisor (132 hotels); 322 (42.9\%) are listed in the Booking.com (204 hotels); 276 (36.8\%) hotels and similar accommodations are listed in the GoldenPages; 271 (36.1\%) hotels and similar accommodations are listed in the YellowPagesUzbekistan; 110 (14.7\%) hotels and similar accommodations are listed in the Expedia.

\begin{tabular}{|c|c|c|}
\hline $\begin{array}{c}\text { Uzbekistan Hotels' Appearance on } \\
\text { Websites }\end{array}$ & $\begin{array}{c}\text { No. of Listed Hotels \& } \\
\text { Similar Accommodations }\end{array}$ & $\begin{array}{c}\text { \% of 750 Hotels \& } \\
\text { Similar Accommodations }\end{array}$ \\
\hline TRIPADVISOR.COM & 496 & $66.1 \%$ \\
\hline BOOKING.COM & 322 & $42.9 \%$ \\
\hline GOLDENPAGES.UZ & 276 & $36.8 \%$ \\
\hline YELLOWPAGES.UZ & 271 & $36.1 \%$ \\
\hline EXPEDIA.COM & 110 & $14.7 \%$ \\
\hline
\end{tabular}

Table 2. Self-constructed by Researchers Source: TripAdvisor, 2018; Booking.com, 2018; GoldenPages, 2018; YellowpagesUzbekistan, 2018; Expedia, 2018. 
After collection and combination of data from GoldenPages and YellowPagesUzbekistan, the sample size has narrowed down to 283 hotels. Criteria for evaluation included: presence of hotels' corporate website; presence of English language selection option; user-friendly (modern) website design; online booking option; distribution of hotels across the cities of the country.

\subsection{Presence \& Working Website}

Analysis revealed that out of 283 hotels, only 151 (53\%) do have the corporate website and $132(47 \%)$ do not have their own corporate website (See Fig.1.).

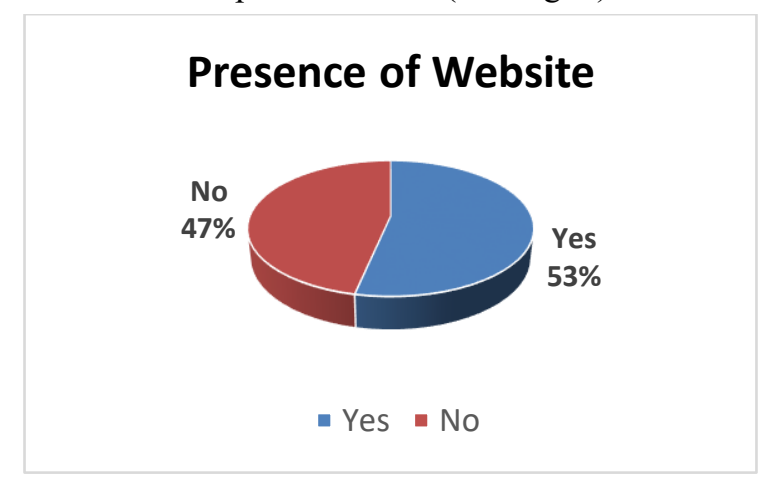

Fig.1. Presence of Website

\section{Working Website}

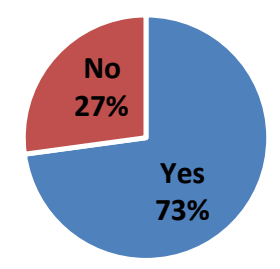

Fig.2. Working Website

Out of 151 hotels with their own corporate websites, 110 (72.8\%) hotels' websites are working, and $41(27.2 \%)$ are not working (under reconstruction or wrong domain) (See Fig.2.). Out of total 283 sampled hotels, only 39\% have working websites.

\section{2- Online Booking Service Availability on Hotels' Website}

Out of 110 working websites 21 (19\%) do not have website booking option available, while 89 (81\%) do have online booking reservation (See Fig.3.).

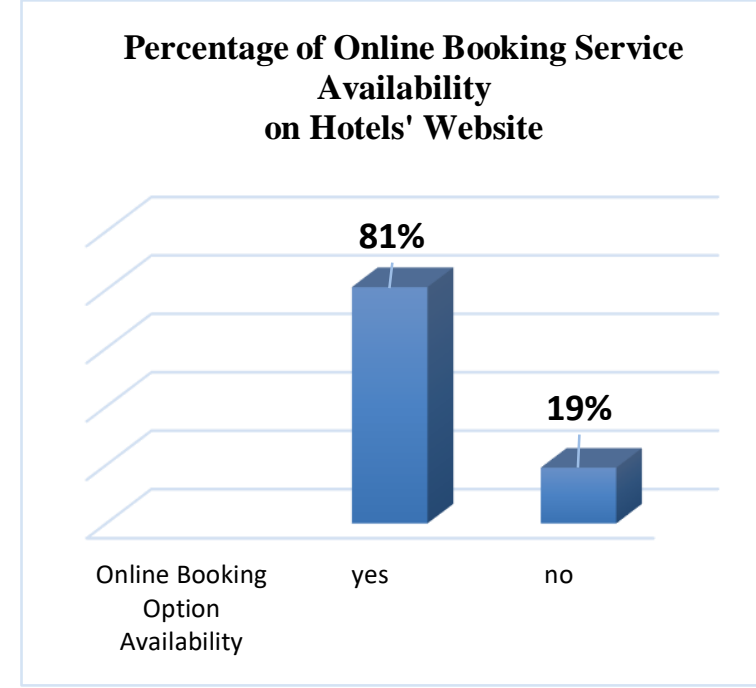

Fig.3. Percentage of Online Booking Service Availability on Hotels' Website

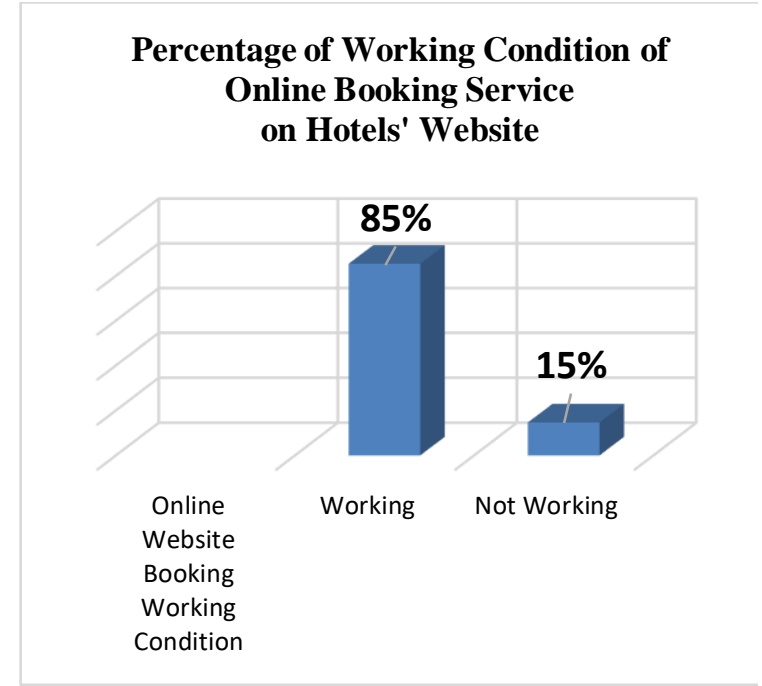

Fig.4. Percentage of Working Condition of Online Booking Service on Hotels' Website

Out of 89 corporate websites with online booking option available 13 (15\%) do not have a working booking form, while $76(85 \%)$ hotels' online booking forms are working. Out of total sample size of 283 hotels, only $27 \%$ of online booking forms are functioning (See Fig.4.).

\section{3- User-Friendly (Modern) Website Design Layout}

Out of 110 working websites slightly more than half i.e. 60 (55\%) hotels have user-friendly ('modern') type of website design, with (50) $45 \%$ remained to be less user-friendly design layout. Out of total sampled 283 hotels, $21 \%$ of hotels' corporate websites have user-friendly layout (See Fig.5.). 


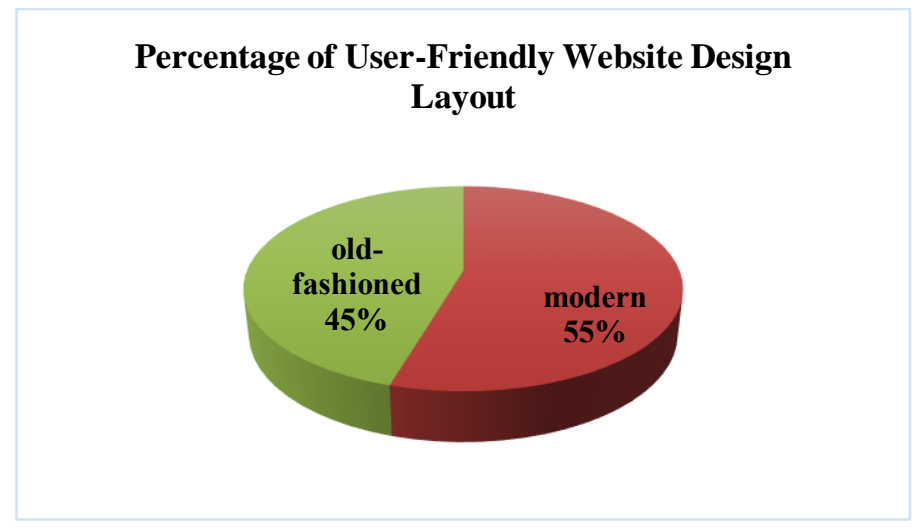

Fig.5. Percentage of User-friendly (modern) Website Design Layout

\section{4- Websites' English Language Version}

Websites have also been evaluated on a presence of English language options and versions. Thus, the findings reveal, that out of 110 working corporate websites, 11 websites $(10 \%)$ do not have English language selection option, while 99 (90\%) websites do have an English language option and version of their website. However, out of total sampled 283 hotels, only 99 hotels (35\%) have English language version of the website (See Fig.6.).

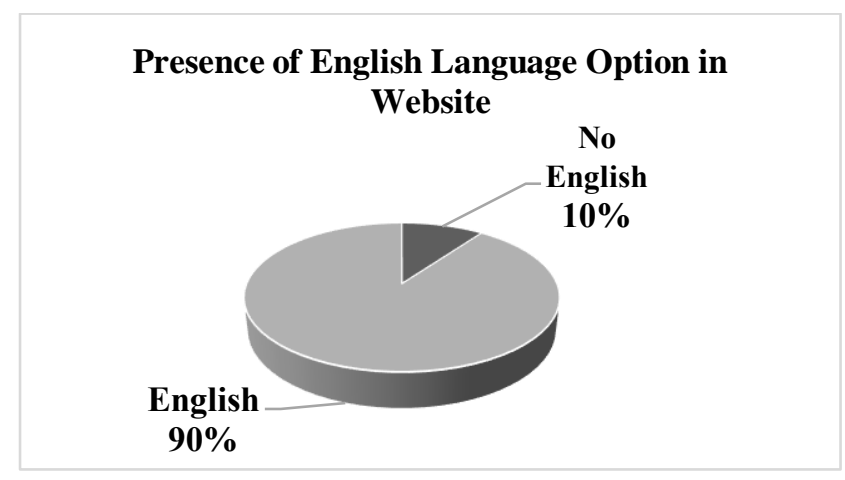

Fig.6. Presence of English Language Option in Website

\section{5- Distribution of Hotels Across Cities of the Country}

When analyzing the number of hotels in different cities of the country, there has been nineteen (19) cities identified. Top three (3) of the cities demonstrate majority of hotels' distribution accounting for 222 (78\%) hotels; namely (1) Tashkent with 109 hotels, (2) Bukhara with 61 hotels and (3) Samarkand with 52 hotels (See Fig.7.). Hotels in top three cities of the country with composition of both good website and working online booking service has been identified as follows:

- In Tashkent out of 109 hotels there are 35 (32.1\%) hotels;

- In Bukhara out of 61 hotels there are $12(19.6 \%)$ hotels;

- In Samarkand out of 52 hotels there are 19 (36.5\%) hotels.

Which tells us, that in top three cities of the country with the majority of hotel distribution, on average, about $29 \%$ of hotels do have both good interactive corporate website with working online booking service. 


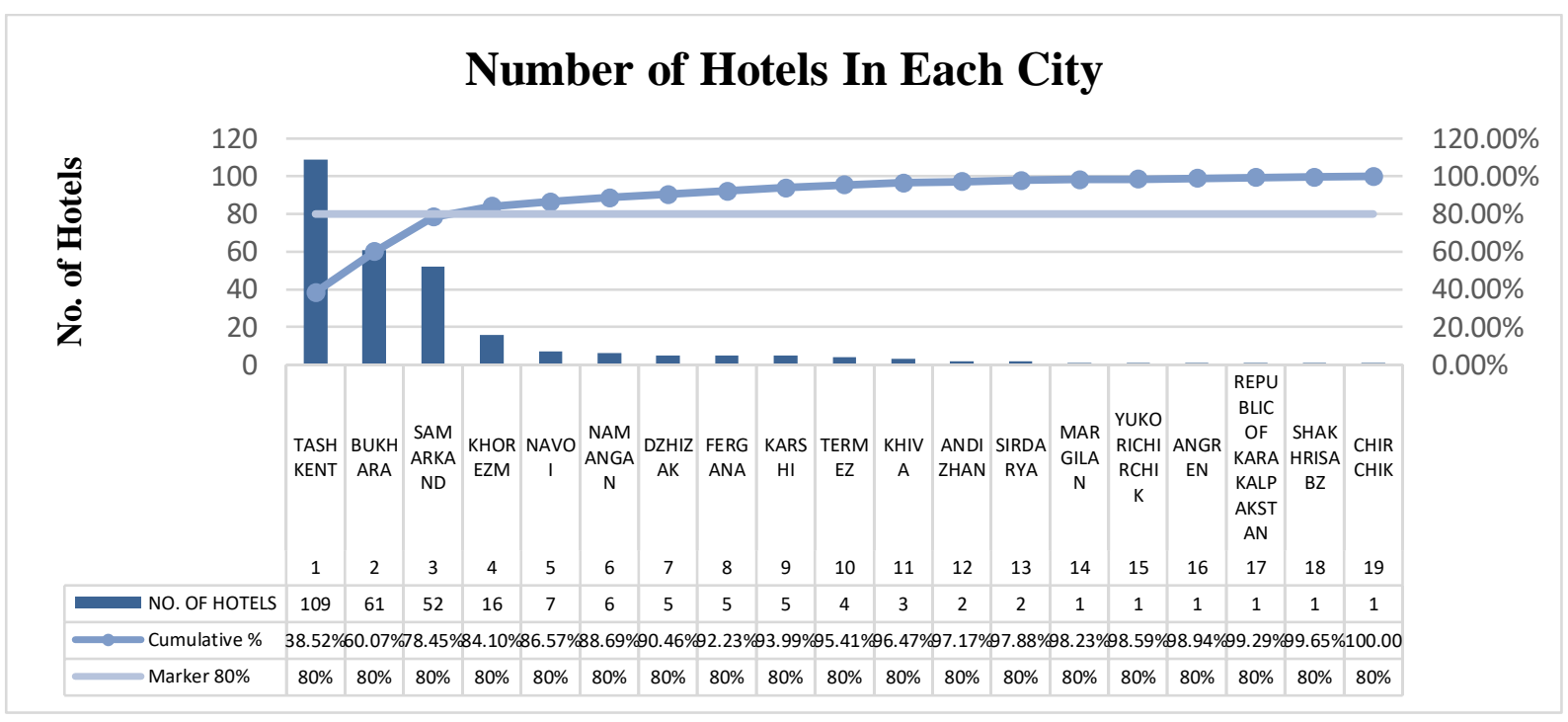

Fig.7. Number/Distribution of Hotels Across Cities of Uzbekistan

\section{Conclusion \& Recommendations}

As was discussed in this research, more and more travelers are using online booking services. They make their decision to reserve a particular hotel based on online reviews and star ratings, and also based on the aesthetics of the hotels' corporate website design layout. It has also been mentioned that hotels in China due to high commission rates by OTAs are working on increasing hotels' direct booking rather than through third parties. It also has been highlighted that hotels have big gaps to fill in terms of handling online booking inquires through their corporate websites.

Our findings reveal that out of 750 hotels and similar accommodations, information about only 283 hotels have been found through online resources. Out of 283 sampled hotels only $39 \%$ have the working corporate website and $27 \%$ of websites offer a working online booking function for the travelers; $21 \%$ have user-friendly website design; $35 \%$ have English language version of the website. It has also been found that top three cities with the majority of hotels distribution accounting for 78\%, fall into Tashkent (109 hotels), Bukhara (61) and Samarkand (52 hotels).

Our findings lead us to the following recommendations:

(1) All of the hotels have to invest into good quality interactive corporate website with high quality photographs;

(2) Website need to have basic 'must have' features such as good quality information about hotels' services along with the updated contact information;

(3) Virtual website tours and 360' degrees view of rooms and hotel is to be present along with the updated brochure information about hotel services which is updated and improved on a continuous basis;

(4) English language version of the website needs to be present in the hotels' corporate website;

(5) 'Book Now' option is to be present on the home page of the hotel with the reservation dates available for traveler, and most importantly it needs to be working well;

(6) Different types of inquiries options have to be available to travelers such as phone, email, online booking form, fax, online assistant and so on, which need to be working appropriately and what is more importantly handled or answered accordingly.

(7) Nowadays, hoteliers need to consider offering mobile version of their corporate website by simplifying the online booking process and converting it into sales;

(8) Consider investing in developing hotels' search engine marketing strategy, so that website can easily be found in search engines such as Google, for example;

(9) Consider updating hotels' contact information not only on the corporate website but in the OTAs that hotel is registered with and in the GoldenPages, and YellowPagesUzbekistan.

The limitations of this study include: the sample of analyzed websites focused only on the country of Uzbekistan, therefore generalizability of findings can be limited; secondly, information about the analyzed sample of hotels has been obtained only from websites listed in the GoldenPages and YellowPagesUzbekistan online, this could lead to subjective judgement.

The findings of this study, not only provide an information about the current situation of online booking services by hotels' website in Uzbekistan with the existing website booking features used by the local hoteliers, but also can help hoteliers to establish and/or improve and upgrade their corporate websites which will bring them to a next 
level of being easily found online and reached by the public, which in turn can help them increase their sales, which in long term, can increase the number of tourists travelling to Uzbekistan.

\section{References}

- $\quad$ ABTA Holiday Habits Report (2017) [Online]. Available at:https://abta.com/assets/uploads/general/Holiday_Habits_Report_2017.pdf [Accessed on 10 February 2018].

- Alexa (2018) The top ranked sites in Travel Category. Available at: https://www.alexa.com/topsites/category/Top/Recreation/Travel [Accessed: 10 January, 2018).

- Alexa (2018) The top ranked sites in Travel Category. Available at: https://www.alexa.com/topsites/category/Top/Recreation/Travel [Accessed: 10 January, 2018).

- Booking.com (2018) About Booking.com. Available at: https://www.booking.com/content/about/general.html [Accessed: 10 January, 2018].

- Booking.com (2018) Uzbekistan :322 properties available. Available at: https://www.booking.com/searchresults.html?label=gen173nr1DCAEoggJCAlhYSDNYBGjuAYgBAZgBMbgBB8gBDdgBAgBAfgBApICAXmoAgM\&sid=a83a6115035b761f29ff5972197f9cf3\&sb=1\&src=searchresults\&src_elem= sb\&error_url=https\%3A\%2F\%2Fwww.booking.com\%2Fsearchresults.html\%3Flabel\%3Dgen173nr1DCAEoggJCAlhYSDNYBGjuAYgBAZgBMbgBB8gBDdgBAgBAfgBApICAXmoAgM\%3Bsid\%3Da83a6115035b761f29ff5972197f9cf3\%3Bclass_interval\%3D1\%3Bd est id $\% 3 \mathrm{D}$ -

2575720\%3Bdest_type\%3Dcity\%3Bdtdisc\%3D0\%3Bgroup_adults\%3D2\%3Bgroup_children\%3D0\%3Bhig hlighted hotels\%3D1511457\%3Binac\%3D0\%3Bindex_postcard\%3D0\%3Blabel_click\%3Dundef\%3Bno_r ooms $\% 3$ D $1 \% 3$ Boffset $\% 3 \mathrm{D} 0 \% 3$ Bpostcard\%3D0\%3Braw_dest_type\%3Dcity\%3Bredirected\%3D1\%3Broom $1 \% 3 \mathrm{DA} \% 252 \mathrm{CA} \% 3 \mathrm{Bsb}$ price_type\%3Dtotal\%3Bss_all\%3D0\%3Bssb\%3Dempty\%3Bsshis\%3D0\%26\%3B $\&$ ss $=$ Uzbekistan\&ssne $=$ Bukhara\&ssne_untouched $=$ Bukhara\&city $=-$

$2575720 \&$ checkin_month $=\&$ checkin_monthday $=\&$ checkin_year $=\&$ checkout_month $=\&$ checkout_monthday 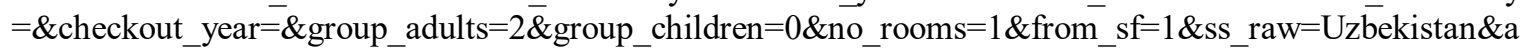 c_position $=0 \&$ ac_langcode $=$ en\&dest_id $=226 \& d e s t$ type $=$ country\&place_id_lat $=41.321 \&$ place_id_lon $=62$. 552\&search_pageview_id=016a824057d501c9\&search_selected=true [Accessed: $10 \mathrm{March}, 2018]$.

- Chan, S. and Law, R. (2006), 'Automatic website evaluations: the case of hotels in Hong Kong', Information Technology \& Tourism, Vol. 8 Nos 3-4, pp. 255-269. Cited in Alessandro Inversini, Lorenzo Masiero, (2014) 'Selling rooms online: the use of social media and online travel agents', International Journal of Contemporary Hospitality Management, Vol. 26 Issue: 2, pp.272-292, Available at: http://dx.doi.org/10.1108/IJCHM-03-2013-0140 [Accessed on: 15 March, 2018].

- D. Abdullaha, K. Jayaraman, S. B. M. Kamal (2015) 'A Conceptual Model of Interactive Hotel Website: The Role of Perceived Website Interactivity and Customer Perceived Value Toward Website Revisit Intention'. Fifth International Conference on Marketing And Retailing (5TH INCOMaR). 2015. Malaysia: Universiti Teknologii MARA Pulau Pinang. Procedia Economics and Finance 37 (2016) 170 - 175. [Online]. Available at: https://www.sciencedirect.com/science/article/pii/S2212567116301095 [Accessed: 10 January, 2018].

- eBizMBAGuide (2018) Top 15 Most Popular Travel Websites. Available at: http://www.ebizmba.com/articles/travel-websites [Accessed: 10 March, 2018].

- Essawy, M. (2006) Testing the Usability of Hotel Websites: The Springboard for Customer Relationship Building. Information Technology \& Tourism 8(1): 47-70. Cited in Dickinger A., Mazanec J. (2008) Consumers' Preferred Criteria for Hotel Online Booking. In: O’Connor P., Höpken W., Gretzel U. (eds) Information and Communication Technologies in Tourism 2008. Springer, Vienna [Online]. Available at: https://doi.org/10.1007/978-3-211-77280-5_22 [Accessed: 15 February, 2018].

- Expedia (2018) Uzbekistan 110 Properties. Available at: https://www.expedia.com/HotelSearch?destination=Uzbekistan\&latLong $=41.773147 \% 2$ C63.121724\&regionId $=11412 \&$ startDate $=\&$ endDat $\mathrm{e}=\&$ rooms $=1 \& \_\mathrm{xpid}=11905 \% 7 \mathrm{C} 1$ \&adults $=2$ [Accessed: 10 January, 2018].

- ExpediaGroup (2018) Global Network of Brands. Available at: https://www.expediagroup.com/expediabrands/ [Accessed: 10 January, 2018].

- ExpediaGroup (2018) Overview. Available at: https://www.expediagroup.com/brands/expedia-com/ [Accessed: 10 January, 2018].

- Failte Ireland National Tourism Development Authority (2013) Tourism Facts 2012. [Online]. Available at: http://www.failteireland.ie/FailteIreland/media/WebsiteStructure/Documents/3_Research_Insights/3_Genera 1_SurveysReports/Tourism_Facts_2012.pdf?ext=.pdf [Accessed on 10 February 2018]. 
- GoldenPages (2018) Hotels in Uzbekistan. Available at: https://www.goldenpages.uz/en/rubrics/?Id=1089 Acessed: 10 January, 2018.

- Google and OTX (2011) MediaTraveler's Road to Decision. Available at: http:/www.thinkwithgoogle.com/insights/library/studies/travelers- road-to-decision-2011 Cited in Asunur CEZAR Hulisi OGUT in Determinants of Domestic and international visitors' online hotel booking. 8th International Strategic Management Conference. 2012. University of Economics and Technology, Ankara. Available at: https://ac.els-cdn.com/S1877042812045387/1-s2.0-S1877042812045387main.pdf? tid=ad37c37a-0977-46e7-94d17b38a3402059\&acdnat=1525685390_6dc1a07c94326aa8e6ca126572ed6724 [Accessed: 15 February 2018].

- Ho et al., 2011 Ho, L.H., Lu, M.H., Ho, H.Y., Peng, T.F., 2011. 'A study of website optimization strategy and implementation'. Advanced Materials Research, Computational Materials Science’, 829-834, http://dx.doi.org/10.4028/www.scientific.net/ AMR.268-270.829. Cited in James N.K. Liu, Elaine Yulan Zhang 'An investigation of factors affecting customer selection of online hotel booking channels'. International Journal of Hospitality Management [Online] 39 (2014) 71-83. Available at: https://www.sciencedirect.com/science/article/pii/S0278431914000218 [Accessed: 10 January, 2018].

- Igor H. Crnojevac, B.Sc. Jadranka Gugic, Sasa Karlovcan (2009). 'eTourism: A comparison of online and offline booking methods and the importance of hotel attributes'. Proceedings of the 20th Central European Conference on Information and Intelligent Systems. 23-25 September 2009. Varazdin, Croatia: Faculty of Organization and Information. Available at: http://archive.ceciis.foi.hr/app/index.php/ceciis/2009/paper/view/265/222 [Accessed on: 15 March, 2018].

- InnovationTactics (2017) Business models compared: Booking.com, Expedia, TripAdvisor. Available at: http://www.innovationtactics.com/business-models-tripadvisor-booking-com-expedia/ [Accessed: 10 January, 2018).

- Internet World Stats (2017) World Internet Usage and Population Statistics. Available at: (https://www.internetworldstats.com/stats.htm [Accessed on: 15 March, 2018]

- Inversini, L. Masiero, (2014) 'Selling rooms online: the use of social media and online travel agents', International Journal of Contemporary Hospitality Management [Online]. Vol. 26 Issue: 2, pp.272-292. Available at: https://doi.org/10.1108/ IJCHM-03-2013-0140 [Accessed:10 January, 2018].

- James N.K. Liu, Elaine Yulan Zhang 'An investigation of factors affecting customer selection of online hotel booking channels'. International Journal of Hospitality Management [Online] 39 (2014) 71-83. [Accessed: 10 January, 2018].

- Kelly Virginia Phelan, Natasa Christodoulidou, Cary C. Countryman, Leonard J. Kistner, (2011) "To book or not to book: the role of hotel web site heuristics". Journal of Services Marketing, Vol. 25 Issue: 2, pp.134148, Available at: https://doi.org/10.1108/08876041111119859 Accessed on: 15 March, 2018].

- $\quad$ Li Li, Maojuan Peng, Nan Jiang, Rob Law (2017) 'An empirical study on the influence of economy hotel website quality on online booking intentions' International Journal Of Hospitality Management [Online. 27 January 2017. Available athttps://www.sciencedirect.com/science/article/pii/S0278431917300233 : [Accessed on 15 March, 2018].

- Marco A. Gardini (2015) 'A Study on the Online Sales Efficiency of Upscale and Luxury Hotels in Germany, Switzerland and Austria' In Advances in Hospitality and Leisure. [Online]: 12 Mar 2015; 173 192.Available at: https://doi.org/10.1016/S1745-3542(06)03010-4 [Accessed on 10 March 2018].

- Marcussen, C.H. (2008), "Trends in European internet distribution - of travel and tourism services. Trends in European internet distribution - of travel and tourism services", Available at:

https://crt.dk/media/50256/Trends_in_European_Internet_Distribution_2009.pdf [Accessed on 10 March $2018]$.

- $\quad$ Miller, 2004 Miller, B., 2004. 'Building E-loyalty of lodging brands.' Journal of Travel \& Tourism Marketing. 17 (2-3), 133-142, http://dx.doi.org/10.1300/J073v17n02 11. Cited in James N.K. Liu, Elaine Yulan Zhang 'An investigation of factors affecting customer selection of online hotel booking channels'. International Journal of Hospitality Management [Online] 39 (2014) 71-83. Available at: https://www.sciencedirect.com/science/article/pii/S0278431914000218 [Accessed: 10 January, 2018 ].

- Ogut and Tas 2011. Cited in Asunur CEZAR Hulisi OGUT in Determinants of Domestic and international visitors' online hotel booking. 8th International Strategic Management Conference. 2012. Ankara: University of Economics and Technology. Available at: https://ac.els-cdn.com/S1877042812045387/1-s2.0S1877042812045387-main.pdf? tid=ad37c37a-0977-46e7-94d17b38a3402059\&acdnat=1525685390_6dc1a07c94326aa8e6ca126572ed6724 [Accessed: 15 February 2018].

- Sanchez, J.-F., \& Satir, A. (2005). 'Hotel yield management using different reservation modes.' International Journal of Contemporary Hospitality Management, 17(2), 136-146. Cited in in Dahlan Abdullah, K. 
Jayaraman, Saiful Bahri Mohd Kamal (2015) 'Conceptual Model of Interactive Hotel Website: The Role of Perceived Website Interactivity and Customer Perceived Value Toward Website Revisit Intention'. Fifth International Conference On Marketing And Retailing (5TH INCOMaR). 2015. Malaysia: Universiti Teknologi MARA Pulau Pinang. Available at: https://ac.els-cdn.com/S2212567116301095/1-s2.0S2212567116301095-main.pdf?_tid=1acf05c6-99c5-4c96-a30bb3a91a529e41\&acdnat=15256777730_1f8f6234b49a2ffb54c5683f377cc558 [Accessed: 15 February 2018].

- ServiceQualitat Niedersachsen (2006). Eine Bestandsaufnahme der ServiceQualitat Touristischer Leistungstrager in Niedersachsen. Hannover: Tourismus Marketing Niedersachsen GmbH. Cited in Marco A. Gardini (2015), 'A Study on the Online Sales Efficiency of Upscale and Luxury Hotels in Germany, Switzerland and Austria' In Advances in Hospitality and Leisure. [Online]: 12 Mar 2015; 173-192. Available at: https://doi.org/10.1016/S1745-3542(06)03010-4 [Accessed: 15 January, 2018].

- Statista (2014) Holiday booking methods used by travelers from the United Kingdom (UK) in 2014 by domestic or overseas travel destinations. Available at: https://www.statista.com/statistics/380950/holidaybooking-methods-used-by-uk-travelers-domestic-and-overseas/ [Accessed on:15 March, 2018].

- $\quad$ Sunmee Choi And Sheryl E. Kimes (2002). 'Electronic Distribution Channels' Effect on Hotel Revenue Management.' Cornell Hotel and Restaurant Administration Quarterly. June 2002. Available at: http://journals.sagepub.com/doi/pdf/10.1177/0010880402433002 [Accessed on: 10 January, 2018].

- The State Committee of the Republic of Uzbekistan on Statistics (2017) Main Indicators of Recreation And Tourism Development In The Republic Of Uzbekistan.Available at: https://stat.uz/en/435-analiticheskiematerialy-en 1/2062-main-indicators-of-recreation-and-tourism-development-in-the-republic-of-uzbekistan [Accessed: 15 January, 2018].

- TripAdvisor (2018) About TripAdvisor. Available at: https://tripadvisor.mediaroom.com/us-about-us [Accessed: 10 January, 2018].

- TripAdvisor (2018) Uzbekistan Hotels. Available at: https://www.tripadvisor.com/Hotels-g293967Uzbekistan-Hotels.html [Accessed: 10 January, 2018].

- Vermeulen, I. E. \& Seegers D.(2009). 'Tried and tested: The impact of online hotel reviews on consumer consideration.' Tourism Management, 30, 23-127 Cited in Asunur CEZAR Hulisi OGUT in Determinants of Domestic and international visitors' online hotel booking. 8th International Strategic Management Conference. 2012. Ankara: University of Economics and Technology. Available at: https://ac.elscdn.com/S1877042812045387/1-s2.0-S1877042812045387-main.pdf?_tid=ad37c37a-0977-46e7-94d17b38a3402059\&acdnat=1525685390_6dc1a07c94326aa8e6ca126572e-d6724 [Accessed: 15 February 2018].

- YellowPagesUzbekistan (2018) Hotels in Uzbekistan : List of hotels of Uzbekistan, their addresses, phone numbers, contacts. Available at: https://en.yellowpages.uz/rubric/hotels [Accessed: 10 January 2018]. 